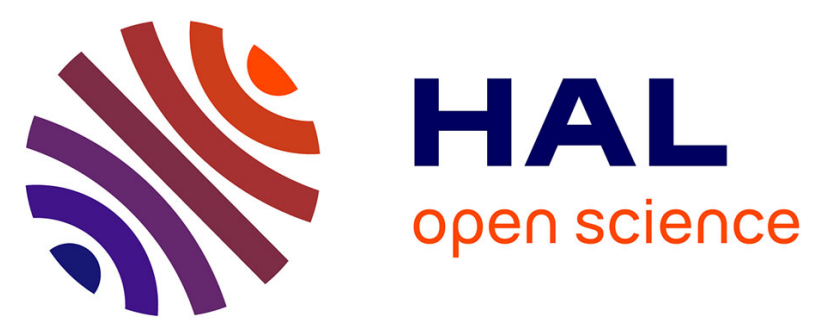

\title{
Effect of copper content on the synthesis and properties of (Mg4-xCux)Al2OH12CO3, nH2O layered double hydroxides.
}

Mourad Intissar, Alain Seron, Fabien Giovannelli, Cecile Autret, Mikael Motelica-Heino, Fabian Delorme

\section{To cite this version:}

Mourad Intissar, Alain Seron, Fabien Giovannelli, Cecile Autret, Mikael Motelica-Heino, et al.. Effect of copper content on the synthesis and properties of $(\mathrm{Mg} 4-\mathrm{xCux}) \mathrm{Al} 2 \mathrm{OH} 12 \mathrm{CO} 3, \mathrm{nH} 2 \mathrm{O}$ layered double hydroxides.. Journal of Materials Science, 2015, 50 (3), pp.1427-1434. 10.1007/s10853-014-8702-5 . insu-01095106

\section{HAL Id: insu-01095106 https://hal-insu.archives-ouvertes.fr/insu-01095106}

Submitted on 5 Jun 2015

HAL is a multi-disciplinary open access archive for the deposit and dissemination of scientific research documents, whether they are published or not. The documents may come from teaching and research institutions in France or abroad, or from public or private research centers.
L'archive ouverte pluridisciplinaire HAL, est destinée au dépôt et à la diffusion de documents scientifiques de niveau recherche, publiés ou non, émanant des établissements d'enseignement et de recherche français ou étrangers, des laboratoires publics ou privés. 


\title{
Effect of copper content on the synthesis and properties of $\left(\mathrm{Mg}_{4-\mathrm{x}} \mathrm{Cu}_{\mathrm{x}}\right) \mathrm{Al}_{2} \mathrm{OH}_{12} \mathrm{CO}_{3}$, $\mathrm{nH}_{2} \mathrm{O}$ Layered Double Hydroxides
}

\author{
Mourad INTISSAR ${ }^{1}$, Alain SERON ${ }^{2}$, Fabien GIOVANNELLI ${ }^{3}$, Cécile AUTRET ${ }^{4}$, \\ Mikael MOTELICA-HEINO $^{1}$ and Fabian DELORME ${ }^{3 *}$
}

${ }^{1}$ Université d'Orléans CNRS/INSU Institut des Sciences de la Terre d'Orléans, UMR 7327 Campus Géosciences 1A, rue de la Férollerie 41071 Orléans cedex, France.

${ }^{2}$ BRGM, 3 Avenue Claude Guillemin, BP 36009, 45060 Orléans Cedex 2, France.

${ }^{3}$ Université François Rabelais de Tours, CNRS, CEA, INSA, GREMAN UMR 7347, IUT de Blois, 15 rue de la chocolaterie, CS 2903, 41029 Blois Cedex, France.

${ }^{4}$ Université François Rabelais de Tours, CNRS, CEA, INSA, GREMAN UMR 7347, Faculté des Sciences et Techniques, parc de Grandmont, 37200 Tours, France.

*: corresponding author. Tel. : +33-2-54-55-21-10 ; Fax : +33-2-54-55-21-09; E-mail : fabiandelorme@yahoo.fr. 


\begin{abstract}
:
In this paper, the substitution of $\mathrm{Mg}$ by $\mathrm{Cu}$ on the synthesis and properties of $\left(\mathrm{Mg}_{4}\right.$ $\left.{ }_{\mathrm{x}} \mathrm{Cu}_{\mathrm{x}}\right) \mathrm{Al}_{2} \mathrm{OH}_{12} \mathrm{CO}_{3}, \mathrm{nH}_{2} \mathrm{O} \mathrm{LDHs}$ have been studied. Samples have been synthesized by the coprecipitation method using varying $\mathrm{pH}$ method. Physicochemical characterization of the obtained samples was performed by a combination of techniques such as X-ray diffraction, SEM, BET specific surface area, UV-Visible spectrometry, EPR spectrometry and thermo-gravimetric analysis. For all the syntheses, whatever the $\mathrm{Mg} / \mathrm{Cu}$ ratio, a single phase was obtained. For low copper contents $(x<2.6)$, the single phase is a rhombohedral LDH. For higher copper contents, a symmetry decrease was observed and the layered hydroxide compound is monoclinic, due to distorted $\mathrm{Cu}(\mathrm{OH})_{2}$ octahedra by Jahn-Teller effect. Additionally, thermal stability of the compounds decreases when $\mathrm{Cu}$ content increases. Samples with the monoclinic cell do not show any affinity for nitrates and an even higher affinity for carbonates compared to $\mathrm{Mg}_{4} \mathrm{Al}_{2}-\mathrm{LDH}$. For the samples with the LDH structure, the captured nitrate content increases as the copper content increases but remains limited. All the samples also lead to amorphous mixed oxide nanoparticles when heated at moderate temperature.
\end{abstract}

Keywords : Anionic clays ; Layered double hydroxides ; Hydrotalcite-like compounds ; Mixed oxide catalysts 


\section{Introduction}

Layered Double Hydroxides (LDHs) are a class of two-dimensional nano-structured anionic clays [1-3]. They have received a growing interest for their potential applications in numerous domains such as in green chemistry for the entrapment of anionic pollutants [4-8], in catalysis [9-12] as oxides precursors $[13,14]$, in medical science as vectors [1517], etc. LDHs can be visualized as a structure made of layers comparable to those of brucite $\mathrm{Mg}(\mathrm{OH})_{2}$, in which some of the $\mathrm{Mg}^{2+}$ cations are substituted by a trivalent metal as $\mathrm{Al}^{3+}$. Such substitution creates a positive charge on the hydroxide layers, which is compensated by anions mostly hydrated in the interlayer domain [2]. The general formula of $\mathrm{LDH}$ is $\left[\mathrm{M}^{2+}{ }_{1-\mathrm{x}} \mathrm{M}^{3+}{ }_{\mathrm{x}}(\mathrm{OH})_{2}\right]\left[\mathrm{A}^{\mathrm{n}-}\right]_{\mathrm{x} / \mathrm{n}} \mathrm{yH}_{2} \mathrm{O}$, where $\mathrm{M}^{2+}$ and $\mathrm{M}^{3+}$ are respectively divalent and trivalent cations occupying octahedral sites within the $(\mathrm{OH})$ layers where $\mathrm{x}$ refers to the ratio $\mathrm{M}^{3+} /\left(\mathrm{M}^{2+}+\mathrm{M}^{3+}\right)$, $\mathrm{x}$ is usually $0.17<\mathrm{x}<0.33$ and $\mathrm{A}^{\mathrm{n}-}$ is in most cases an exchangeable anion [18,19]. LDHs are generally synthesized by the coprecipitation method at a constant $\mathrm{pH}[1,3,20-23]$ or at varying $\mathrm{pH}$ [24-26], but other synthesis routes were also reported as hydrothermal route [27], sol gel route [28], etc. Many combinations for divalent and trivalent cations have been reported $[18,19]$, the most studied cationic composition being $\mathrm{Mg}_{4} \mathrm{Al}_{2}-\mathrm{LDH}$ as a natural or synthetic material. Due to different stacking sequences, LDHs can present either hexagonal or rhombohedral symmetry $[29,30]$.

For many applications especially in catalysts and catalyst supports $[3,10,11]$, LDHs with transition metal cations have received a special interest. In particular, copper containing 
LDHs present a great interest in this field as well as the derived oxide products obtained after a moderate thermal treatment [31-33]. However, it is not easy to obtain a $\mathrm{Cu}-\mathrm{Al}$ $\mathrm{LDH}$, even if the ionic radius of $\mathrm{Mg}^{2+}(0.72 \AA)$ is comparable to the one of $\mathrm{Cu}^{2+}(0.73 \AA)$ [34]. Indeed, $\mathrm{Cu}(\mathrm{OH})_{2}$ does not present a brucite structure but a structure of corrugated layers similar to $\gamma$-FeOOH lepidocrocite [35] due to Jahn-Teller effect [36,37]. Controversial results have been published related to copper containing LDHs. The first detailed attempt to obtain a $\mathrm{Cu}-\mathrm{Al}-\mathrm{LDH}$ was reported in literature by Yamaoka et al. in 1989 [38] : the authors did precipitation using solutions with different $\mathrm{Cu} / \mathrm{Al}$ molar ratios and obtained lamellar compounds exhibiting a monoclinic symmetry with different kinds of impurities such as $\mathrm{Na}_{2} \mathrm{Al}_{2}\left(\mathrm{CO}_{3}\right)_{2} \cdot 2.9 \mathrm{H}_{2} \mathrm{O}$, copper nitrate, malachite or $\mathrm{Na}_{2} \mathrm{Cu}\left(\mathrm{CO}_{3}\right)_{2} \cdot 3 \mathrm{H}_{2} \mathrm{O}$. Park et al. [39] obtained a layered $\mathrm{Cu}_{0.67} \mathrm{Al}_{0.33}(\mathrm{OH})_{2}\left(\mathrm{SO}_{4}\right)_{0.15}\left(\mathrm{CO}_{3}\right)_{0.015}, 0.5 \mathrm{H}_{2} \mathrm{O}$ compound with a structure different from that of LDHs using a copper(II) amine complex solution. Alejandre et al. [40] were interested in syntheses of a pure $\mathrm{CuAl}-\mathrm{LDH}$ with different $\mathrm{Cu} / \mathrm{Al}$ ratios: the precipitation of both cations gave, in all cases, a copper hydrotalcite phase accompanied with other phases such as malachite, gibbsite or gerhardite. Lwin et al. [41] have synthesized Cu-Al $\mathrm{LDHs}$ with different $\mathrm{Cu} / \mathrm{Al}$ ratios using sodium carbonate as alkali. They found a layered compound that they consider to be a LDH, with malachite impurity. Fogg et al. [42] reported the synthesis of an orthorhombic $\mathrm{Cu}-\mathrm{Al}-\mathrm{LDH}$ with a $\mathrm{Cu} / \mathrm{Al}$ ratio of $1 / 4$ from $\gamma$ $\mathrm{Al}(\mathrm{OH})_{3}$ in hydrothermal conditions. Trujillano et al. [43] have synthesized a $\mathrm{Cu}_{4} \mathrm{Al}_{2^{-}}$ LDH presenting a rhombohedral 3R packing of the layers. Britto and Kamath [44] reported the synthesis of pure $\mathrm{CuAl}-\mathrm{LDH}$ with a $\mathrm{Cu} / \mathrm{Al}$ ratio $=2$, which presents a monoclinic symmetry whereas for $\mathrm{Cu} / \mathrm{Al}=0.25$ it presents an orthorhombic symmetry. 
To overcome the difficulty to reach pure copper LDH compounds, some authors have tried to synthesize ternary LDHs. Auer et al. [45] have reported the synthesis of a pure $\left(\mathrm{Mg}_{2} \mathrm{Cu}_{2}\right) \mathrm{Al}_{2}$-compound with a LDH structure. Carja et al. [46] reported the study of the textural properties of an $\mathrm{MgAl}$ hydrotalcite substituted by $\mathrm{Cu}^{2+}$ or Fe$^{3+}$. Such substituted materials preserve a LDH structure, though the authors have limited their study to a $\left(\mathrm{Mg}_{4} \mathrm{Cu}_{2}\right) \mathrm{Al}_{2}-\mathrm{LDH}$. Melian-Cabrera et al. [47] reported the presence of rosasite as an impurity in their Cu-Zn-Al LDHs syntheses. Kannan et al. [48] synthesized $\left(\mathrm{Mg}_{1} \mathrm{Cu}_{5}\right) \mathrm{Al}_{2-},\left(\mathrm{Ni}_{1} \mathrm{Cu}_{5}\right) \mathrm{Al}_{2}-$ and $\left(\mathrm{Co}_{1} \mathrm{Cu}_{5}\right) \mathrm{Al}_{2}-$ compounds with a $\mathrm{LDH}$ structure whereas $\mathrm{CuAl}-\mathrm{LDH}$ presented gerhardite or malachite impurities. $\mathrm{Cu} / \mathrm{Cr}$ cationic combination exhibits a rhombohedral LDH structure [49]. However, as determined by EXAFS, this compound presents also a cationic ordering, corrugated layers and the presence of two $\mathrm{Cu}-\mathrm{O}$ distances.

The aim of this study was to clarify the effect of copper in LDHs in terms of structure and properties, especially thermal stability and nitrates affinity. The solid solution $\left(\mathrm{Mg}_{4-}\right.$ $\left.{ }_{x} \mathrm{Cu}_{\mathrm{x}} \mathrm{Al}_{2}-\mathrm{CO}_{3}\right)$ was chosen to study the effects of $\mathrm{Cu}$ content on synthesis, structural and thermal properties.

\section{Experimental section}

$\left(\mathrm{Mg}_{4-\mathrm{x}} \mathrm{Cu}_{\mathrm{x}}\right) \mathrm{Al}_{2}(\mathrm{OH})_{12} \mathrm{CO}_{3} \cdot \mathrm{nH}_{2} \mathrm{O}$ LDH samples with $\mathrm{x}=0$, 0.6, 1.4, 2, 2.6, 3, 3.4, 3.8 and 4 have been synthesized. 
All the syntheses have been realized using deionized water. Pure $\mathrm{Cu}\left(\mathrm{NO}_{3}\right)_{2}$ (Aldrich, 99.99\%), $\mathrm{Mg}\left(\mathrm{NO}_{3}\right)_{2} .9 \mathrm{H}_{2} \mathrm{O}$ (Panreac, 98\%), $\mathrm{Al}\left(\mathrm{NO}_{3}\right)_{3} .9 \mathrm{H}_{2} \mathrm{O}$ (Panreac, 98\%), $\mathrm{NaOH}$ (Panreac, 99\%), $\mathrm{Na}_{2} \mathrm{CO}_{3}$ (Labosi) were used. All materials were prepared using the varying $\mathrm{pH}$ method [25]. Experimentally, $700 \mathrm{ml}$ of an aqueous solution of the mixed cations salts containing the desired ratio was precipitated by a solution of mixed $3.5 \mathrm{M}$ $\mathrm{NaOH}$ and $1 \mathrm{M} \mathrm{Na} \mathrm{Na}_{3}$ under an air atmosphere at $35^{\circ} \mathrm{C}$. The mixed solution of $\mathrm{NaOH} / \mathrm{Na}_{2} \mathrm{CO}_{3}$ was introduced dropwisely at constant rate through a peristaltic pump. During the addition, measurement of the $\mathrm{pH}$ values was performed by a Heitolab P310 $\mathrm{pH}$ meter. The slurry was stirred 24 hours at $60^{\circ} \mathrm{C}$, and then centrifuged at $4000 \mathrm{rpm}$ during 5 min (Jouan CR412). The supernatant was eliminated and the sample was washed three times with room temperature deionized water. Then, the sample was dried in a furnace at $75^{\circ} \mathrm{C}$ overnight.

The anionic affinity of the samples was studied according to the protocol developed by Delorme et al. [26]. Briefly, it consists in dispersing amorphous mixed oxides, obtained by a moderate thermal treatment of the LDH studied samples, in an aqueous solution containing $\left[\mathrm{CO}_{3}{ }^{2-}\right]=\left[\mathrm{SO}_{4}{ }^{2-}\right]=1 / 2\left[\mathrm{NO}_{3}{ }^{-}\right]=0.1 \mathrm{~mol} / \mathrm{L}$ at room temperature during 24 hours under vigorous stirring to obtain LDH reconstruction. It should be noted that the anion exchange capacity of the amorphous mixed oxides added within the solution is lower than the amount of each anions present in the solution. Consequently, the whole amount of the mixed oxides could be fully reconstructed using only one single anionic species if the relative affinities of the three anions are very different. Then the sample were separated by centrifugation, washed three times with deionized water and then dried 
at $75^{\circ} \mathrm{C}$ overnight in a furnace. Amorphous mixed oxides were synthesized by a moderate thermal treatment (PROLABO VOLCA MC18 furnace) of LDH samples during 2 hours under air atmosphere at a temperature determined from $\mathrm{TG}$ curves from $210^{\circ} \mathrm{C}$ up to $360^{\circ} \mathrm{C}$ depending on the composition.

Carbonate concentrations were determined by measurements of $\mathbf{C}$ content using a Horiba carbon/sulfur analyzer EMIA-820 V, whereas nitrate and sulfate concentrations were measured by ionic chromatography (Dionex AS50). Limit of quantification (LoQ) in the case of carbon is $0.01 \%$, whereas nitrates and sulfates are determined down to $5 \mathrm{mg} / \mathrm{L}$ concentrations.

Powder X-ray diffraction patterns (PXRD) were obtained with a Siemens D5000 diffractometer using a Co $\mathrm{K}_{\alpha}$ source. The PXRD was operated at $40 \mathrm{kV}$ and $30 \mathrm{~mA}$ at room temperature. Scans were recorded from 4 to $84^{\circ}(2 \theta)$, with a step of $0.02^{\circ}$ and a counting time of 1s per step. A multipoint adsorptometer (Micrometrics Tristar 3000) was used to determine the specific surface areas. They were determined from the nitrogen adsorption isotherm at $77 \mathrm{~K}$ according to the BET method. The samples were previously outgassed at $75^{\circ} \mathrm{C}$ for $72 \mathrm{~h}$. UV-Visible spectra were obtained on compacted powder samples with an integrating sphere device (Labsphere) on a Perkin Elmer lambda 20 UVVis spectrometer. The spectra were acquired in the range of $200-1100 \mathrm{~nm}$ with a scan speed of $240 \mathrm{~nm}$ per minute at room temperature. 
Electron spin resonance (ESR) measurements were performed with a Bruker EMX 6/1 spectrometer operating around $9.5 \mathrm{GHz}$ (X-band). The applied dc magnetic field was varied from 0 to $7000 \mathrm{G}$. The modulation field had amplitude of $1 \mathrm{mT}$ and a frequency of $100 \mathrm{kHz}$. The sensitivity of the ESR technique is such that a very small amount of powder $(\approx 100 \mu \mathrm{g})$ is sufficient. The ESR spectra were recorded at room temperature.

Thermal gravimetric (TG) and differential thermal analyses (DTA) were performed simultaneously and recorded with a SETARAM TG-DTA 92 thermogravimetric analyzer at a typical rate of $10^{\circ} \mathrm{C} \cdot \mathrm{min}^{-1}$ under air atmosphere $\left(0.51 . \mathrm{h}^{-1}\right)$. Metal analysis was performed with an ICP-AES (Jobin-Yvon type JY 166) instrument after mineralization of samples in concentrated $\mathrm{HCl}$.

\section{Results and Discussion.}

Results of chemical analyses for the different samples are summarized in table 1 . The $\mathrm{Mg} / \mathrm{Cu} / \mathrm{Al}$ molar ratios in the solids are in good agreement with those of the starting solutions. Therefore, all cations of the reacting solution have been precipitated by the $\mathrm{NaOH} / \mathrm{Na}_{2} \mathrm{CO}_{3}$ solution addition.

Figure 1 presents the evolution of the $\mathrm{pH}$ during the coprecipitation of cations while adding the solution of mixed $\left(\mathrm{NaOH} / \mathrm{Na}_{2} \mathrm{CO}_{3}\right)$ for $\mathrm{x}=0,0.6,1.4,2.6$, and 4 . This evolution is characterized by different plateaus as already reported by several authors $[3,21,24]$. It was reported that in the case of $\mathrm{Mg}_{6} \mathrm{Al}_{2}-\mathrm{LDHs}$, the $\mathrm{Al}$ cations precipitate at a 
$\mathrm{pH}$ between 3.4 and 7.1 while $\mathrm{Mg}$ cations mainly precipitate at $\mathrm{pH}$ between 8 and 10 [25]. This is consistent with the $\mathrm{pH}$ curve of the $\mathrm{Mg}_{4} \mathrm{Al}_{2}-\mathrm{LDH}$. When the $\mathrm{Cu}$ content increases, more $\left(\mathrm{NaOH} / \mathrm{Na}_{2} \mathrm{CO}_{3}\right)$ solution is needed to observe the first $\mathrm{pH}$ sharp transition. However, the second plateau is shorter when $\mathrm{Cu}$ content increases. Then $\mathrm{pH}$ curves are similar whatever the $\mathrm{Cu}$ content. This difference at low $\mathrm{pH}$ is probably due to the $\mathrm{Cu}^{2+}$ cations precipitation as malachite, as shown in figure 2 (coprecipitation stopped at $\mathrm{pH}=5.5)$ whereas $\mathrm{Mg}^{2+}$ cations only precipitates for $\mathrm{pH}$ values higher than 8 . As the $\mathrm{pH}$ curves are similar after the second plateau, all the syntheses have been stopped when $\mathrm{pH}$ reaches 10.5 . The syntheses lead to a fine white powder for the $\mathrm{Mg}_{4} \mathrm{Al}_{2}$ composition and fine bluish powders when $\mathrm{Cu}$ cations are introduced.

\subsection{Structural characterization}

XRD patterns recorded at room temperature are presented in figure 3. All the patterns show a single phase with (001) peaks characteristic of a lamellar structure. The X-ray powder diffraction pattern of the $\mathrm{Mg}_{4} \mathrm{Al}_{2}-\mathrm{LDH}$ shows peaks at $7.58 \AA\left(\mathrm{d}_{003}\right) 3.78 \AA\left(\mathrm{d}_{006}\right)$ $2.58 \AA\left(\mathrm{d}_{012}\right), 2.31 \AA\left(\mathrm{d}_{015}\right), 1.96 \AA\left(\mathrm{d}_{018}\right), 1.52 \AA\left(\mathrm{d}_{110}\right), 1.49 \AA \mathrm{d}\left({ }_{113}\right)$ and $1.41 \AA\left(\mathrm{d}_{116}\right)$, which are similar to those reported by several authors for the $\mathrm{Mg}_{4} \mathrm{Al}_{2}-\mathrm{CO}_{3}$ system (Quintinite-3T PDF-00-051-1525). The calculated $c$ distance (figure 4), as reported below, gives a value of $22 \AA$. Thus this result gives a distance of the interlayer space of $3.3 \AA$ which is in accordance with a planar orientation of carbonates anions in the interlamellar space. The c parameter does not significantly evolve as it is mainly influenced by the anion size in the interlayer space. 
As the $\mathrm{Cu}$ content increases, the a parameter increases (figure 4). This is consistent with the slightly larger size of $\mathrm{Cu}^{2+}(0.73 \AA)$ compared to that of $\mathrm{Mg}^{2+}(0.71 \AA)$ cations [34]. An increase of the full width at half maximum (FWHM) of the (110) and (113) diffraction peaks when the $\mathrm{Cu}^{2+}$ content increases means that the incorporation of $\mathrm{Cu}^{2+}$ cations decreases the crystallinity within the layer. Since $x=3$ new peaks are observed, mainly in the $(40-70)^{\circ} 2 \theta$ angular domain and become more pronounced as the $\mathrm{Cu}$ content increases. When $x=4$ these peaks can be indexed in a monoclinic cell using the cell parameters $\left(\mathrm{a}=15.21 \AA, \mathrm{b}=2.9 \AA \mathrm{c}=5.86 \AA, \beta=100.32^{\circ}\right.$. This is consistent with the data reported by Yamaoka et al. [38] and Britto and Kamath [44]. Between $\mathrm{x}=2.6$ and $\mathrm{x}$ $=3.4$ a gradual transition from the rhombohedral $\mathrm{Mg}_{4} \mathrm{Al}_{2}-\mathrm{LDH}$ structure to the monoclinic $\mathrm{Cu}_{4} \mathrm{Al}_{2}$ structure is observed (figure 3).

The local environments of $\mathrm{Cu}^{2+}$ cations have been determined by ESR measurements at room temperature for each composition (figure 5). For $\mathrm{x}=0.6$, the measurement shows a typical signal relating to $\mathrm{Cu}^{2+}$ in octahedral site with an anisotropic orthorhombic site distortion related to a Jahn-Teller effect and a hyperfine structure [50]. This structure corresponds to the interaction between the $\mathrm{Cu}$ nucleus $(\mathrm{I}=3 / 2)$ and the un-paired electron. As the copper concentration increases, the hyperfine structure is strongly attenuated because the paramagnetic interactions become significant.

The UV-visible spectra of the samples with different copper contents are presented in figure 6 . All samples present a maximum absorption around $750 \mathrm{~nm}$. This band is due to 
the ${ }^{2} \mathrm{E}_{\mathrm{g}}(\mathrm{D}) \rightarrow{ }^{2} \mathrm{~T}_{2 \mathrm{~g}}(\mathrm{D})$ transition of $\mathrm{Cu}^{2+}$ in octahedral configuration. The broadness of this band is due to the distortion of $\mathrm{Cu}^{2+}$ octahedra due to the Jahn Teller effect [51]. A band observed near $218 \mathrm{~nm}$ with a shoulder around $280 \mathrm{~nm}$ can be ascribed to charge transfer processes [50]. The relative intensity of the shoulder increases with the copper content up to $x=2$. Then at $x=2.6$, the relative intensity of the shoulder is similar to the spectra at $x$ $=0.6$. After this decrease, the relative intensity of the shoulder increases once again up to $x=4$, leading to a similar spectra at $x=3$ and $x=2$. This decrease of the relative intensity of the shoulder is probably linked to the crystallographic transition. This indicates that the beginning of the crystallographic transition is closed to $\mathrm{x}=2.6$.

The different spectrometry characterizations show that Jahn-Teller effect affects $\mathrm{Cu}^{2+}$ octahedra even for the lowest $\mathrm{Cu}$ contents. However for low copper contents $(\mathrm{x}<2.6)$ it does not affect significantly the XRD patterns and samples present the LDH rhombohedral symmetry. For higher copper content, Jahn-Teller effect leads to a symmetry lowering, and samples present a monoclinic cell.

The SEM images confirm the absence of secondary phases whatever the copper content (figure 7a-c). In general the $\mathrm{LDH}$ crystals present a plate-like morphology and a hexagonal shape $[18,19]$. Samples with the LDH structure (from $x=0$ up to $x=2.6$ ) consist of homogeneous small sub-hexagonal plate-like particles, of about $50 \mathrm{~nm}$ (figure 7a and 7b). Samples with monoclinic cell (figure 7c) present larger plate-like particles (more than $100 \mathrm{~nm}$ ). 
BET specific surface area measurements are consistent with the SEM images. Indeed, samples with the LDH structure present similar specific surface area values of 64.74 , 67.30 and $67.35 \mathrm{~m}^{2} \cdot \mathrm{g}^{-1}$ for $\mathrm{x}=0,0.6$ and 2 respectively, whereas the sample with monoclinic cell $(\mathrm{x}=4)$ presents a lower specific surface area of $41.32 \mathrm{~m}^{2} \cdot \mathrm{g}^{-1}$. This specific surface area decrease is consistent with an increase of the size of the particles as observed by SEM.

\subsection{THERMAL PROPERTIES AND ANION AFFINITY}

Figure 8 presents the DTA curves for $\left(\mathrm{Mg}_{4-\mathrm{x}} \mathrm{Cu}_{\mathrm{x}}\right) \mathrm{Al}_{2}-\mathrm{LDH}$ samples with $\mathrm{x}=0,0.6,1.4,2$, 3.4 and 4. The six curves exhibit the typical behavior of LDHs with two main features. The first one, associated to the removal of adsorbed water and interlayer water molecules is shifted monotonously to lower temperatures as the copper content increases, from $242^{\circ} \mathrm{C}$ for $\mathrm{x}=0$ to $197^{\circ} \mathrm{C}$ for $\mathrm{x}=4$. The same behavior is observed for the second DTA peak from $410^{\circ} \mathrm{C}$ for $\mathrm{x}=0$ to circa $250^{\circ} \mathrm{C}$ for $\mathrm{x}=4$. For samples with high copper content, the second peak appears as a shoulder of the first peak. The second feature is due to the removal of hydroxyl groups from the brucite layers and of the interlayer carbonate anions as carbon dioxide. This step corresponds to the collapse of the LDH lamellar structure and the formation of the so-called "amorphous mixed oxides". TG curves (not presented here), present the usual correlated weight losses that support this interpretation. Figure 8 clearly shows that incorporating copper into the $\mathrm{Mg}_{4} \mathrm{Al}_{2}-\mathrm{LDH}$ decreases the thermal stability of the compound whatever the crystallographic structure. 
Due to their anion exchange properties, LDHs can be used for environmental depollution. Delorme et al. [26] have shown that the cationic composition can influence the anionic affinity of LDHs. Therefore, anionic affinity of the copper containing samples relative to carbonates, sulfates and nitrates has been studied according to the protocol developed by these authors. All the samples lead to amorphous mixed oxides after the heat treatment (Table 2) and reconstructed their structure when contacted with the carbonate-sulfatenitrate aqueous solution, even if their crystallinity is lower than that of the pristine materials : figure 9 presents, as an example, the XRD patterns of the pristine LDH, the amorphous mixed oxide and the reconstructed LDH for the sample with $x=3$. Table 2 shows the relative anions proportions trapped within the layers during the reconstruction of the samples with $\mathrm{x}=0,0.6,1.4,3$ and 3.4. Samples with the rhombohedral and the monoclinic structures exhibit different behavior. For the sample with $\mathrm{x}=0$, no nitrates are detected and $90.5 \%$ of the anions used for the reconstruction of the LDH crystalline structure are carbonates when only $9.5 \%$ are sulfates. Then, when the copper content increases, a slight amount of captured nitrates appears and increases. However, after the crystallographic transition, samples with the monoclinic cell exhibit a different behavior : nitrates were not detected and $95 \%$ of the anions used for the sample reconstruction are carbonates when only $5 \%$ are sulfates.

Even if it increases with the copper content, the affinity for nitrates remains limited and does not qualify $\left(\mathrm{Mg}_{4-\mathrm{x}} \mathrm{Cu}_{\mathrm{x}}\right) \mathrm{Al}_{2}(\mathrm{OH})_{12} \mathrm{CO}_{3} \cdot \mathrm{nH}_{2} \mathrm{O}$ LDHs as suitable materials for environmental nitrates depollution. 


\section{Conclusions}

$\left(\mathrm{Mg}_{4-\mathrm{x}} \mathrm{Cu}_{\mathrm{x}}\right) \mathrm{Al}_{2}(\mathrm{OH})_{12} \mathrm{CO}_{3} \mathrm{nH}_{2} \mathrm{O} \mathrm{LDH}$ samples with $\mathrm{x}=0,0.6,1.4,2,2.6,3,3.4,3.8$ and 4 have been synthesized by the varying $\mathrm{pH}$ method. Structural studies have shown that for all the samples a single phase has been obtained. For low copper contents $(\mathrm{x}<2.6)$, the single phase is a rhombohedral LDH. For higher copper contents, a symmetry decrease is observed and the layered hydroxide compound is monoclinic, due to distorted $\mathrm{Cu}(\mathrm{OH})_{2}$ octahedra by Jahn-Teller effect. DTA/TG analyzes show that the thermal stability of the compounds decreases monotonously when $\mathrm{Cu}$ content increases. The effect of the copper content on the anionic affinity has been evaluated by studying the reconstruction of the layered double hydroxide structure from mixed oxides obtained by the heat treatment of the $\left(\mathrm{Mg}_{4-\mathrm{x}} \mathrm{Cu}_{\mathrm{x}}\right) \mathrm{Al}_{2}$-samples, in aqueous solutions containing carbonates, sulfates and nitrates. It shows that samples with the monoclinic cell do not show any affinity for nitrates and an even higher affinity for carbonates compared to $\mathrm{Mg}_{4} \mathrm{Al}_{2}-\mathrm{LDH}$. For the samples with the rhombohedral structure, the captured nitrate ratio increases as the copper content increases but remains limited. Such limited affinity for nitrates does not qualify $\left(\mathrm{Mg}_{4-\mathrm{x}} \mathrm{Cu}_{\mathrm{x}}\right) \mathrm{Al}_{2}(\mathrm{OH})_{12} \mathrm{CO}_{3} \cdot \mathrm{nH}_{2} \mathrm{O} \mathrm{LDHs}$ as suitable materials for environmental nitrates depollution. However, all the samples lead to amorphous mixed oxide nanoparticles when heated at moderate temperature that present a great potential for catalysis applications. 


\section{References}

[1] Miyata S. (1983) Anion-exchange properties of hydrotalcite-like compounds, Clays and Clay Minerals 31: 305-311.

[2] Reichle W.T. (1986) Synthesis of anionic clay minerals (mixed metal hydroxides, hydrotalcite), Solid States Ionics 22: 135-141.

[3] Cavani F., Trifiro F., Vaccari A. (1991) Hydrotalcite-type anionic clays : preparation, properties and applications, Catalysis Today 11: 173-301.

[4] You Y., Vance G.F., Zhao H. (2001) Selenium adsorption on Mg-Al and Zn-Al layered double hydroxides, Applied Clay Science 20: 13-25.

[5] Seida Y., Nakano Y. (2002) Removal of phosphate by layered double hydroxides containing iron, Water Res. 36: 1306-1312.

[6] Delorme F., Seron A., Gautier A., Crouzet C. (2007) Comparison of the fluoride, arsenate and nitrate anions water depollution potential of a calcined quintinite, a layered double hydroxide compound, Journal of Materials Science 42: 5799-5804.

[7] Delorme F., Seron A. (2012) Anionic depollution by layered hydroxides. In: Carillo, A.C. Griego, D.A. (Eds.) Hydroxides: Synthesis, Types and Applications, Novapublishers, New York, pp 169-194.

[8] Paikaray S., Hendry M.J., Essilfie-Dughan J. (2013) Controls on arsenate, molybdate, and selenate uptake by hydrotalcite-like layered double hydroxides, Chemical Geology 345: 130-138. 
[9] Tichit D., Lhouty M.H., Guida A., Chiche B.H., Figueras F., Auroux A., Bartalini D., Garrone E. (1995) Textural properties and catalytic activity of hydrotalcites, Journal of Catalysis 151: 50-59.

[10] Kagunya W., Hassan Z., Jones W. (1996) Catalytic properties of layered double hydroxides and their calcined derivatives, Inorg. Chem. 35: 5970-5974.

[11] Vaccari A. (1998) Preparation and catalytic properties of cationic and anionic clays, Catalysis Today 41: 53-71.

[12] Xu Z.P., Zhang J., Adebajo M.O., Zhang H., Zhou C. (2011) Catalytic applications of layered double hydroxides and derivatives, Applied Clay Science 53: $139-150$.

[13] Moroz T., Razvorotneva L., Grigorieva T., Mazurov M., Arkhipenko D., Prugov V. (2001) Formation of spinel from hydrotalcites-like minerals and destruction of chromite implanted by inorganic salts, Applied Clay Science 18: 29-36.

[14] Delorme F., Fernandez Martin C., Marudhachalam P., Guzman G., Ovono Ovono D., Fraboulet O. (2012) Synthesis of thermoelectric $\mathrm{Ca}_{3} \mathrm{Co}_{4} \mathrm{O}_{9}$ ceramics with high ZT values from a $\mathrm{Co}^{\mathrm{II}} \mathrm{Co}^{\mathrm{III}}$-Layered Double Hydroxide precursor, Materials Research Bulletin 47: 3287-3291.

[15] Choy J-H. (2004) Intercalative route to heterostructured nanohybrid, Journal of Physics and Chemistry of Solids 65: 373-383.

[16] Choy J-H., Choi S-J., Oh J-M., Park T. (2007) Clay minerals and layered double hydroxides for novel biological applications, Applied Clay Science 36: 122-132. 
[17] Rives V., Del Arco M., Martin C. (2013) Layered double hydroxides as drug carriers and for controlled release of non-steroidal antiinflammatory drugs (NSAIDs): A review, Journal of Controlled Release 169: 28-39.

[18] Rives V. (Ed.) (2001) Layered Double Hydroxides: Present and Future, NovaSciences Publishers, New York, pp 1-499.

[19] Duan X., Evans D.G. (Eds.) (2006) Layered Double Hydroxides; Structure and Bonding 119, Springer, Berlin, pp 1-234.

[20] Yun S.K., Pinnavaia T.J. (1995) Water content and particle texture of synthetic hydrotalcite-like layered double hydroxides, Chem. Mater. 7: 348-354.

[21] Crepaldi E.L., Pavan P.C., Valim J.B. (2000) Comparative study of the coprecipitation methods for the preparation of Layered Double Hydroxides, J. Braz. Chem. Soc. 11: 1-18.

[22] Intissar M., Segni R., Payen C., Besse J-P., Leroux F. (2002) Trivalent Cation Substitution Effect into Layered Double Hydroxides $\mathrm{Co}_{2} \mathrm{Fey}_{\mathrm{Al}}-\mathrm{y}(\mathrm{OH})_{6} \mathrm{Cl} \cdot \mathrm{nH}_{2} \mathrm{O}$ : Study of the Local Order: Ionic Conductivity and Magnetic Properties, Journal of Solid State Chemistry 167: 508-516.

[23] Giovannelli F., Zaghrioui M., Autret-Lambert C., Delorme F., Seron A., Chartier T., Pignon B. (2012) Magnetic properties of Ni(II)-Mn(III) LDHs, Materials Chemistry and Physics 137: 55-60.

[24] Boclair J.W., Braterman P.S. (1999) Layered double hydroxide stability. 1. Relative stabilities of layered double hydroxides and their simple counterparts, Chem. Mater. 11: 298-302. 
[25] Seron A., Delorme F. (2008) Synthesis of layered double hydroxides (LDHs) with varying $\mathrm{pH}$ : a valuable contribution to the study of $\mathrm{Mg} / \mathrm{Al} \mathrm{LDH}$ formation mechanism, Journal of Physics and Chemistry of Solids 69: 1088-1090.

[26] Delorme F., Seron A., Vergnaud B., Galle-Cavalloni P., Jean-Prost V., Manguin J. (2013) Evidence of the influence of the cationic composition on the anionic affinity of layered double hydroxides, Journal of Materials Science 48: 52735279 .

[27] Mascolo G. (1995) Synthesis of anionic clays by hydrothermal crystallisation of amorphous precursors, Applied Clay Science 10: 21-30.

[28] Prinetto F., Ghiotti G., Graffin P., Tichit D. (2000) Synthesis and characterization of sol-gel $\mathrm{Mg} / \mathrm{Al}$ and $\mathrm{Ni} / \mathrm{Al}$ layered double hydroxides and comparison with coprecipitated samples, Microporous and Mesoporous Materials 39: 229-247.

[29] Bookin A.S., Drits V.A. (1993) Polytype diversity of the hydrotalcite-like minerals. I. Possible polytypes and their diffraction features, Clays and Clay Minerals 41: 551-557.

[30] Bookin A.S., Cherkashin V.I., Drits V.A. (1993) Polytype diversity of the hydrotalcite-like minerals. II. Determination of the polytypes of experimentally studied varieties, Clays and Clay Minerals 41: 558-564.

[31] Velu S., Swamy C.S. (1996) Selective C-alkylation of phenol with methanol over catalysts derived from copper-aluminium hydrotalcite-like compounds, Applied Catalysis A: General 145: 141-153.

[32] Alejandre A., Medina F., Rodriguez X., Salagre P., Sueiras J.E. (1999) Preparation and Activity of $\mathrm{Cu}-\mathrm{Al}$ Mixed Oxides via Hydrotalcite-like Precursors 
for the Oxidation of Phenol Aqueous Solutions, Journal of Catalysis 188: 311324.

[33] Sanchez Valente J., Figueras F., Gravelle M., Kumbhar P., Lopez J., Besse J-P. (2000) ) Basic properties of the mixed oxides obtained by thermal decomposition of hydrotalcites containing different metallic compositions, Journal of Catalysis 189: $370-381$.

[34] Shannon R.D. (1976) Revised effective ionic radii and systematic studies of interatomic distances in halides and chalcogenides, Acta Cryst. A 32: 751-767.

[35] Jaggi V.H., Oswald H.R. (1961) Die kristallstruktur des kupferhydroxids, $\mathrm{Cu}(\mathrm{OH})_{2}$, Acta Cryst. 14: 1041-1045.

[36] Oswald H.R., Reller A., Schmalle H.W., Dubler E. (1990) Structure of copper(II) hydroxide, $\mathrm{Cu}(\mathrm{OH})_{2}$, Acta Cryst. C 46: 2279-2284.

[37] Cudennec Y., Lecerf A. (2001) Étude du type structural de $\gamma-\mathrm{FeO}(\mathrm{OH})_{(\mathrm{s})}$ et comparaison avec la structure de $\mathrm{Cu}(\mathrm{OH})_{2(\mathrm{~s})}$, C.R. Acad. Sci. Paris, Chimie/Chemistry $4: 885-891$.

[38] Yamaoka T., Abe M., Tsuji M. (1989) Synthesis of Cu-Al hydrotalcite like compound and its ion exchange property, Mater. Res. Bull. 24: 1183-1199.

[39] Park I.Y., Kuroda K., Kato C. (1990) Preparation of complex copper aluminum double hydroxide phases from copper (II) ammine complex solutions, Solid State Ionics 42; 197-203.

[40] Alejandre A., Medina F., Salagre P., Correig X., Sueiras J.E. (1999) Preparation and study of $\mathrm{Cu}-\mathrm{Al}$ mixed oxides via hydrotalcite-like precursors, Chem. Mater. 11: 939-948. 
[41] Lwin Y., Yarmo M.A., Yaakob Z., Mohamad A.B., Daud W.R.W. (2001) . Synthesis and characterization of $\mathrm{Cu}-\mathrm{Al}$ layered double hydroxides, Materials Research Bulletin 36: 193-198.

[42] Fogg A.M., Williams G.R., Chester R., O'Hare D. (2004) A novel family of layered double hydroxides $-\left[\mathrm{MAl}_{4}(\mathrm{OH})_{12}\right]\left(\mathrm{NO}_{3}\right)_{2} \mathrm{xH}_{2} \mathrm{O}(\mathrm{M}=\mathrm{Co}, \mathrm{Ni}, \mathrm{Cu}, \mathrm{Zn})$, Journal of Materials Chemistry 14: 2369-2371.

[43] Trujillano R., Holgado M.J., Pigazo F., Rives V. (2006) Preparation, physicochemical characterisation and magnetic properties of $\mathrm{Cu}-\mathrm{Al}$ layered double hydroxides with $\mathrm{CO}_{3}{ }^{2-}$ and anionic surfactants with different alkyl chains in the interlayer, Physica B 373: 267-273.

[44] Britto S., Kamath P.V. (2009) Thermal, solution and reductive decomposition of $\mathrm{Cu}-\mathrm{Al}$ layered double hydroxides into oxide products, Journal of Solid State Chemistry 182: 1193-1199.

[45] Auer S.A., Gredig S.V., Köppel R.A., Baiker A. (1999) Synthesis of methylamines from $\mathrm{CO}_{2}, \mathrm{H}_{2}$ and $\mathrm{NH}_{3}$ over $\mathrm{Cu}-\mathrm{Mg}$-Al mixed oxides, Journal of Molecular Catalysis A : Chemical 141: 193-203.

[46] Carja G., Nakamura R., Aida T., Niiyama H. (2001) Textural properties of layered double hydroxides : effect of magnesium substitution by copper and iron, Microporous and Mesoporous Materials 47: 275-284.

[47] Melian-Cabrera I., Lopez Granados M., Fierro J.L.G. (2002) Thermal decomposition of a hydrotalcite-containing $\mathrm{Cu}-\mathrm{Zn}-\mathrm{Al}$ precursor: thermal methods combined with an in situ DRIFT study, Phys. Chem. Chem. Phys. 4: 3122-3127. 
[48] Kannan S., Rives V., Knözinger H. (2004) High-temperature transformations of Cu-rich hydrotalcites, Journal of Solid State Chemistry 177: 319-331.

[49] Roussel H., Briois V., Elkaim E., De Roy A., Besse J.P. (2000) Cationic order and structure of $[\mathrm{Zn}-\mathrm{Cr}-\mathrm{Cl}]$ and $[\mathrm{Cu}-\mathrm{Cr}-\mathrm{Cl}]$ layered double hydroxides : a XRD and EXAFS study, J. Phys. Chem. B 104: 5915-5923.

[50] Le Nestour A., Gaudon M., Villeneuve G., Andriessen R., Demourgues A. (2007) Steric and Electronic Effects Relating to the $\mathrm{Cu}^{2+} \mathrm{Jahn}-\mathrm{Teller}$ Distortion in $\mathrm{Zn}_{1-}$ ${ }_{x} \mathrm{Cu}_{x} \mathrm{Al}_{2} \mathrm{O}_{4}$ Spinels, Inorg. Chem. 46: 2645-2658.

[51] Rives V., Kannan S. (2000) Layered double hydroxides with the hydrotalcite-type structure containing $\mathrm{Cu}^{2+}, \mathrm{Ni}^{2+}$ and $\mathrm{Al}^{3+}$, Journal of Materials Chemistry 10: 489495. 


\section{FIGURE CAPTION}

Figure $1: \mathrm{pH}$ value evolution when adding $\left(\mathrm{NaOH} / \mathrm{Na}_{2} \mathrm{CO}_{3}\right)$ solution for samples with $\mathrm{x}$ $=0,0.6,1.4,2.6$, and 4 .

Figure 2 : XRD pattern of a sample with $\mathrm{x}=4$ when coprecipitation is stopped at $\mathrm{pH}=$ 5.5, showing malachite (PDF 00-041-1390) impurity (*).

Figure 3 : XRD patterns of samples with $\mathrm{x}=0,0.6,1.4,2,2.6,3 ., 3.4,3.8$ and 4.

Figure 4 : a- and c/3-cell parameters evolution for samples with $\mathrm{x}=0,0.6,1.4$ and 2.6.

Figure 5 : EPR spectra of samples with $\mathrm{x}=0,0.6$ and 2.

Figure 6 : UV-Visible spectra of samples with $\mathrm{x}=0.6,1.4,2,2.6,3$ and 4 .

Figure 7 : SEM images of samples with, a) $\mathrm{x}=0, \mathrm{~b}) \mathrm{x}=2$ and c) $\mathrm{x}=4($ scale bar $=500$ nm).

Figure 8 : DTA curves for $\left(\mathrm{Mg}_{4-\mathrm{x}} \mathrm{Cu}_{\mathrm{x}}\right) \mathrm{Al}_{2}-\mathrm{LDH}$ samples with $\mathrm{x}=0,0.6,1.4,2,3.4$ and 4 .

Figure 9: XRD patterns of samples with $x=3$, a) pristine LDH, b) amorphous mixed oxide, c) reconstructed LDH. 
Table 1 : Chemical analyses and cell parameters of samples with $\mathrm{x}=0,0.6,1.4,2,2.6,3$, $3.4,3.8$ and 4.

Table 2 : Influence of the copper content on the relative proportion of carbonate, sulfate and nitrate anions after reconstruction in samples with $\mathrm{x}=0,0.6,1.4,3$, and 3.4. 


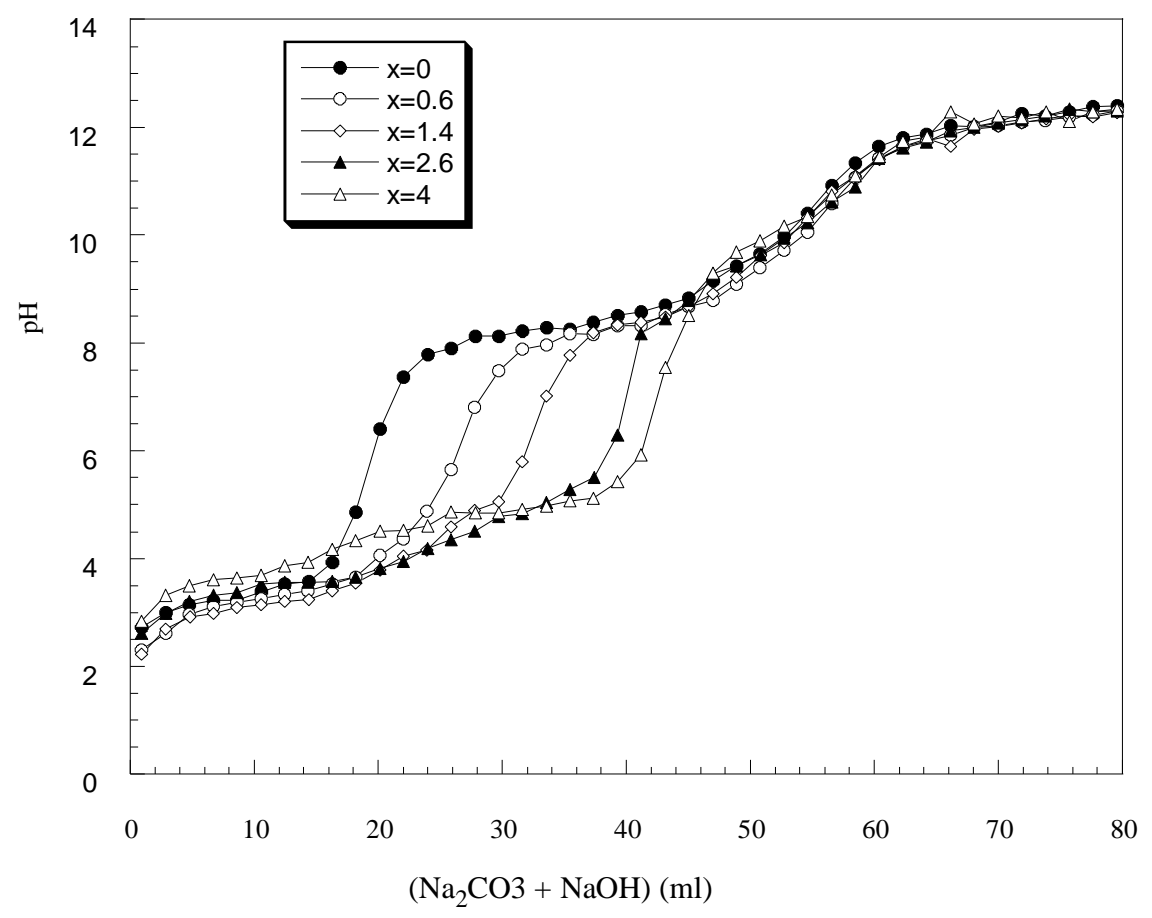

Figure 1 


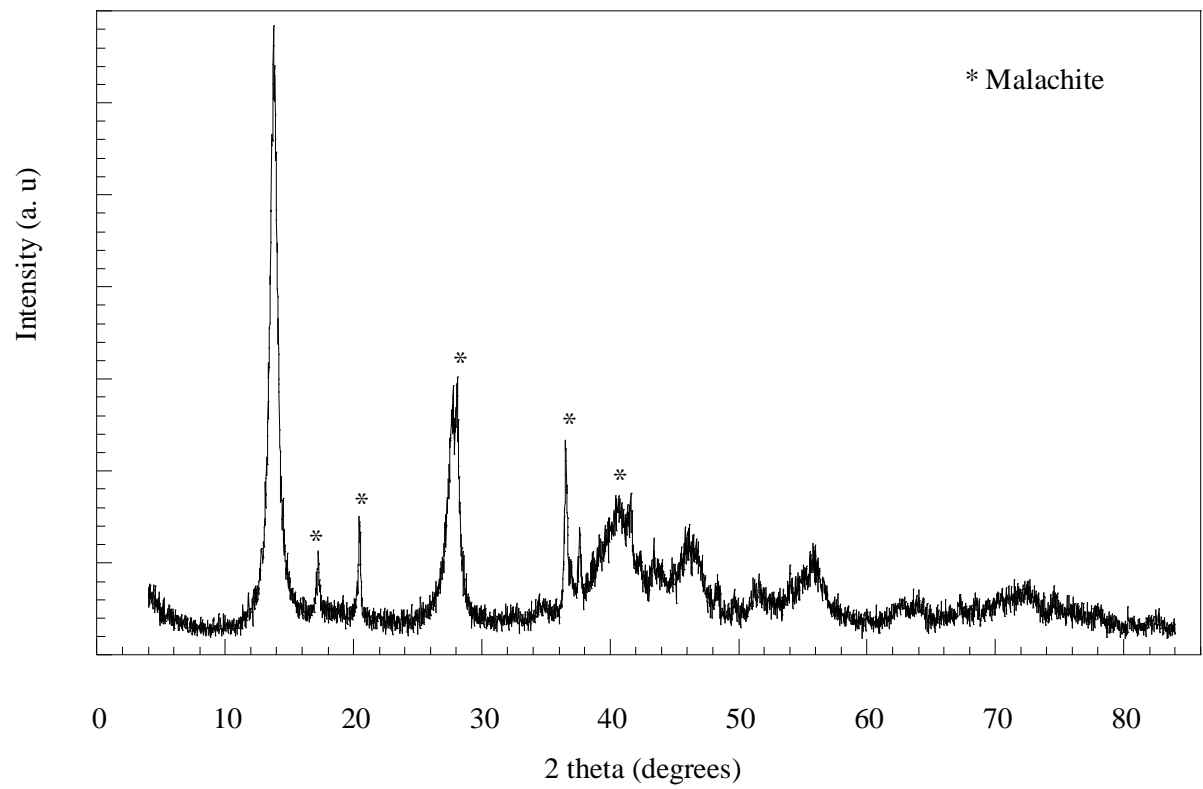

Figure 2 


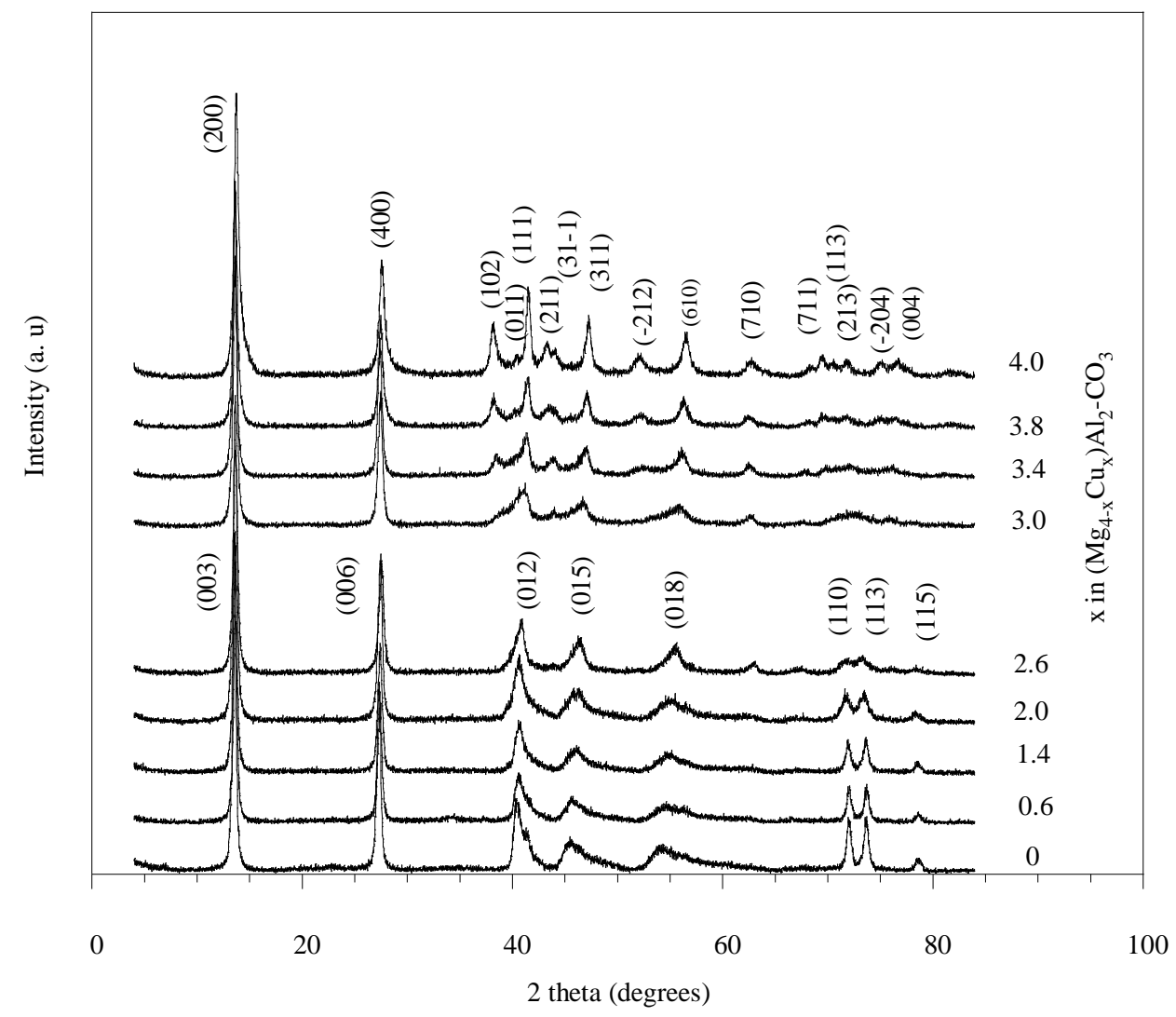

Figure 3 


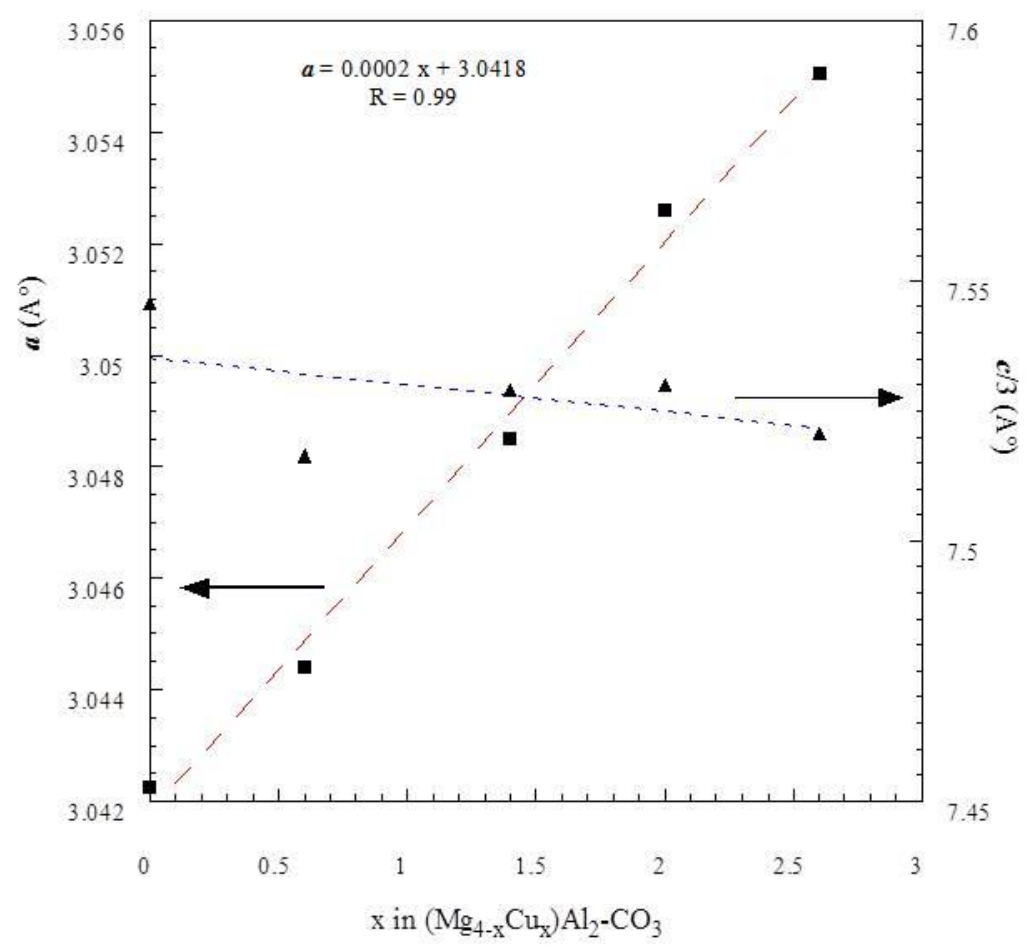

Figure 4 


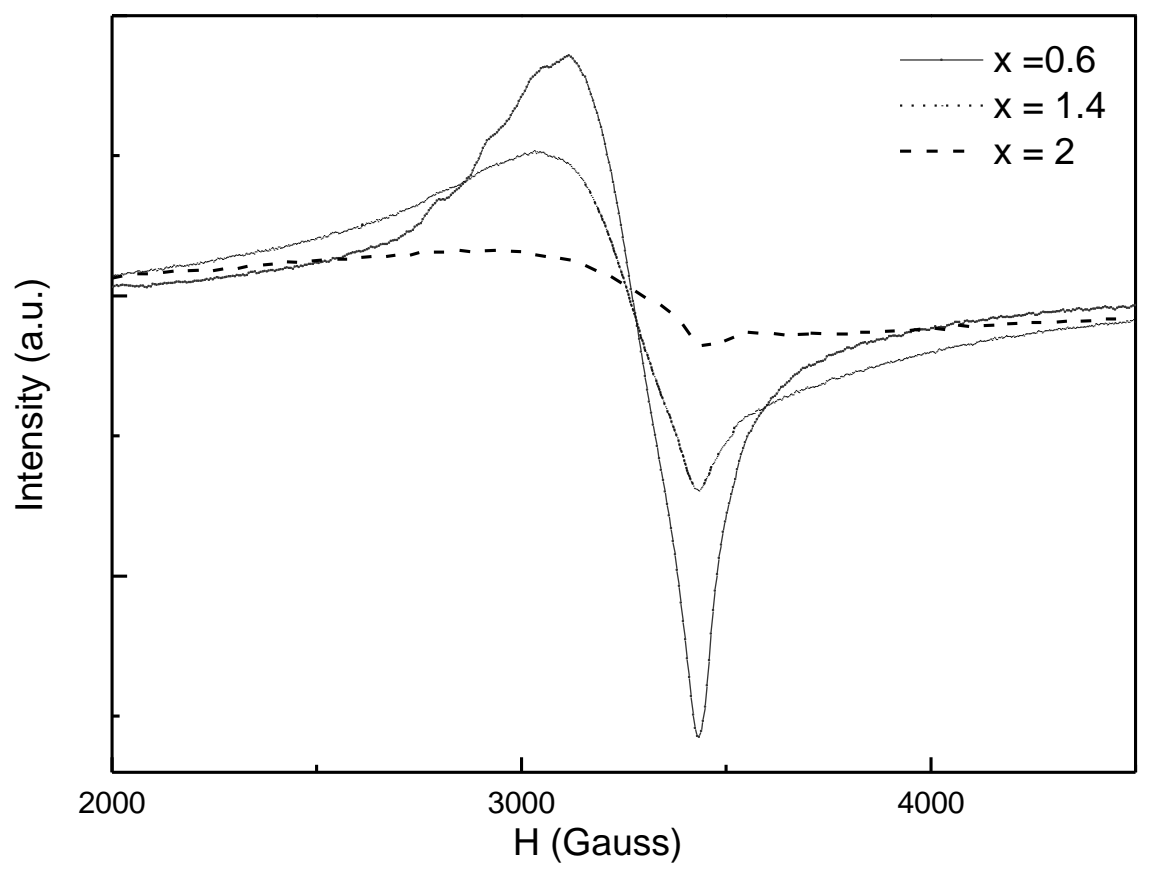

Figure 5 


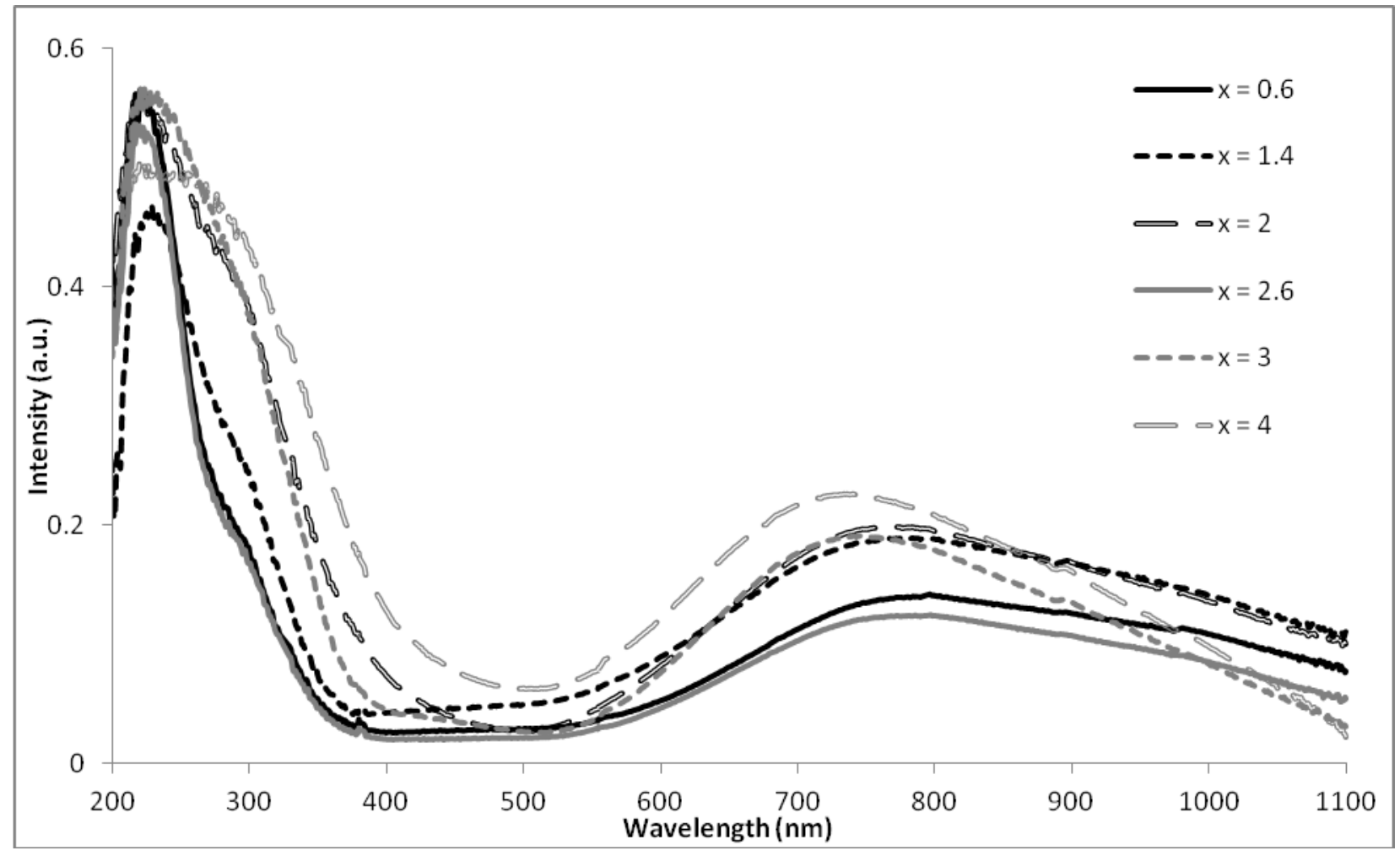

Figure 6 


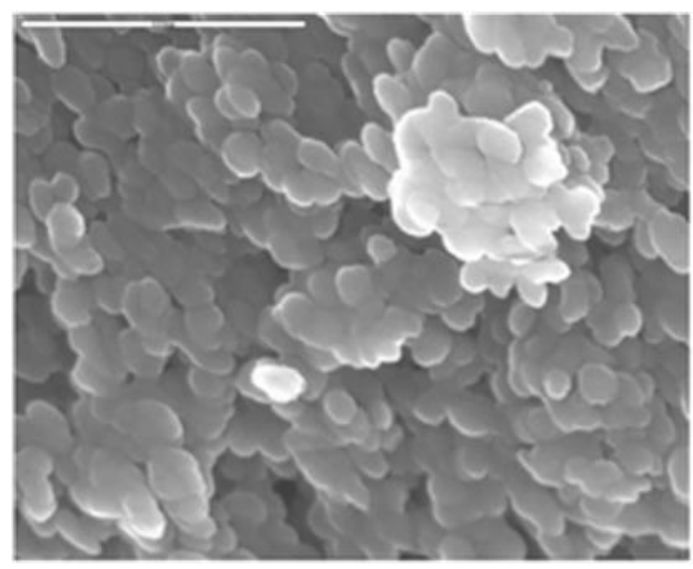

a)

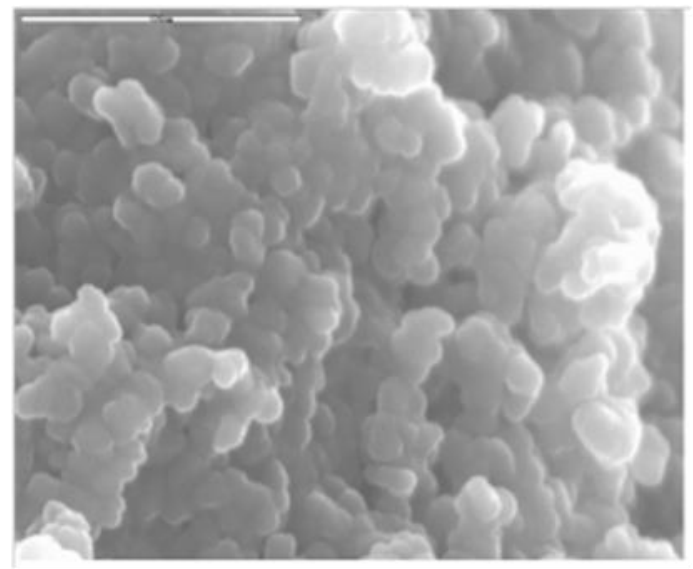

b)

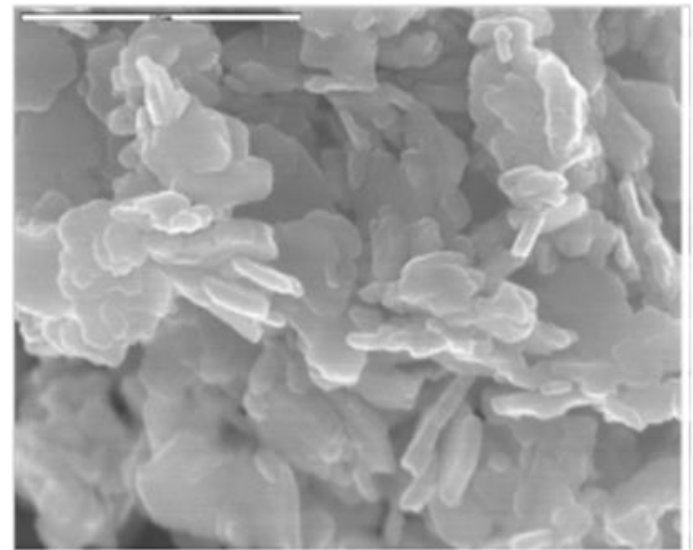

c)

Figure 7 


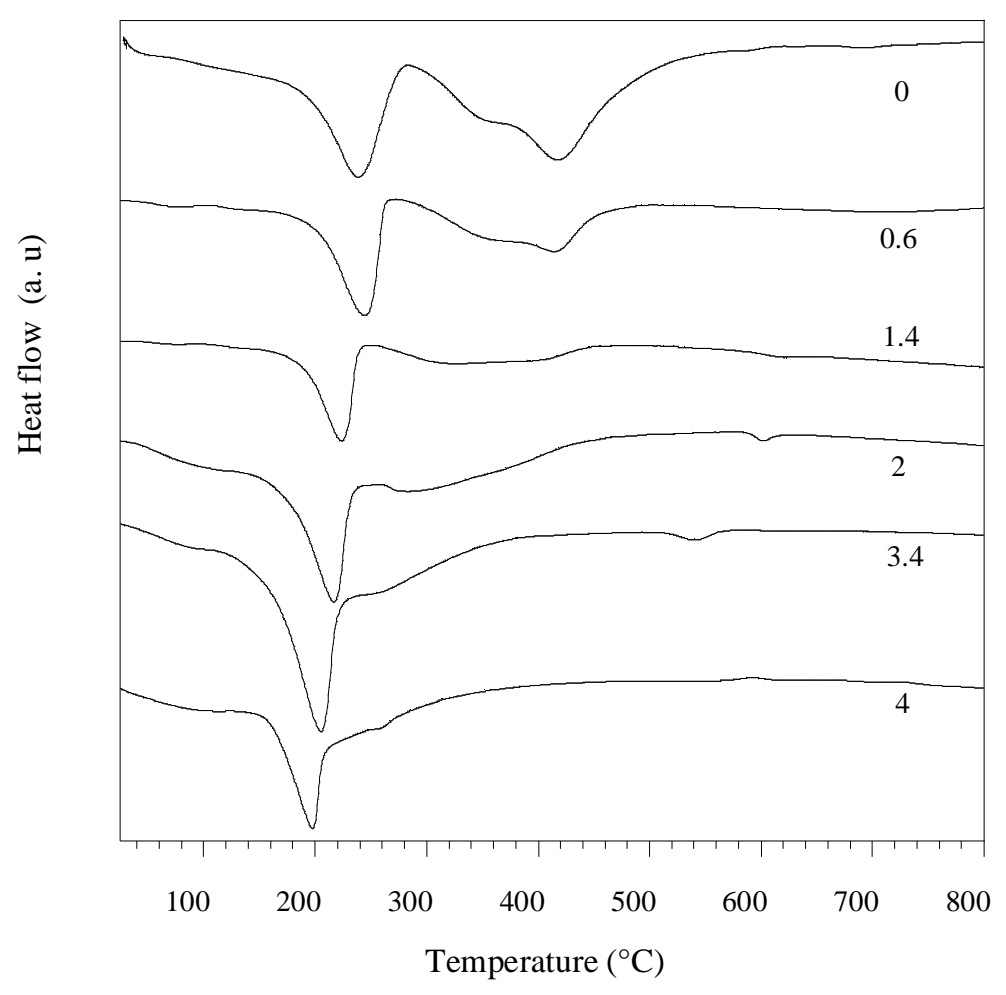

Figure 8 


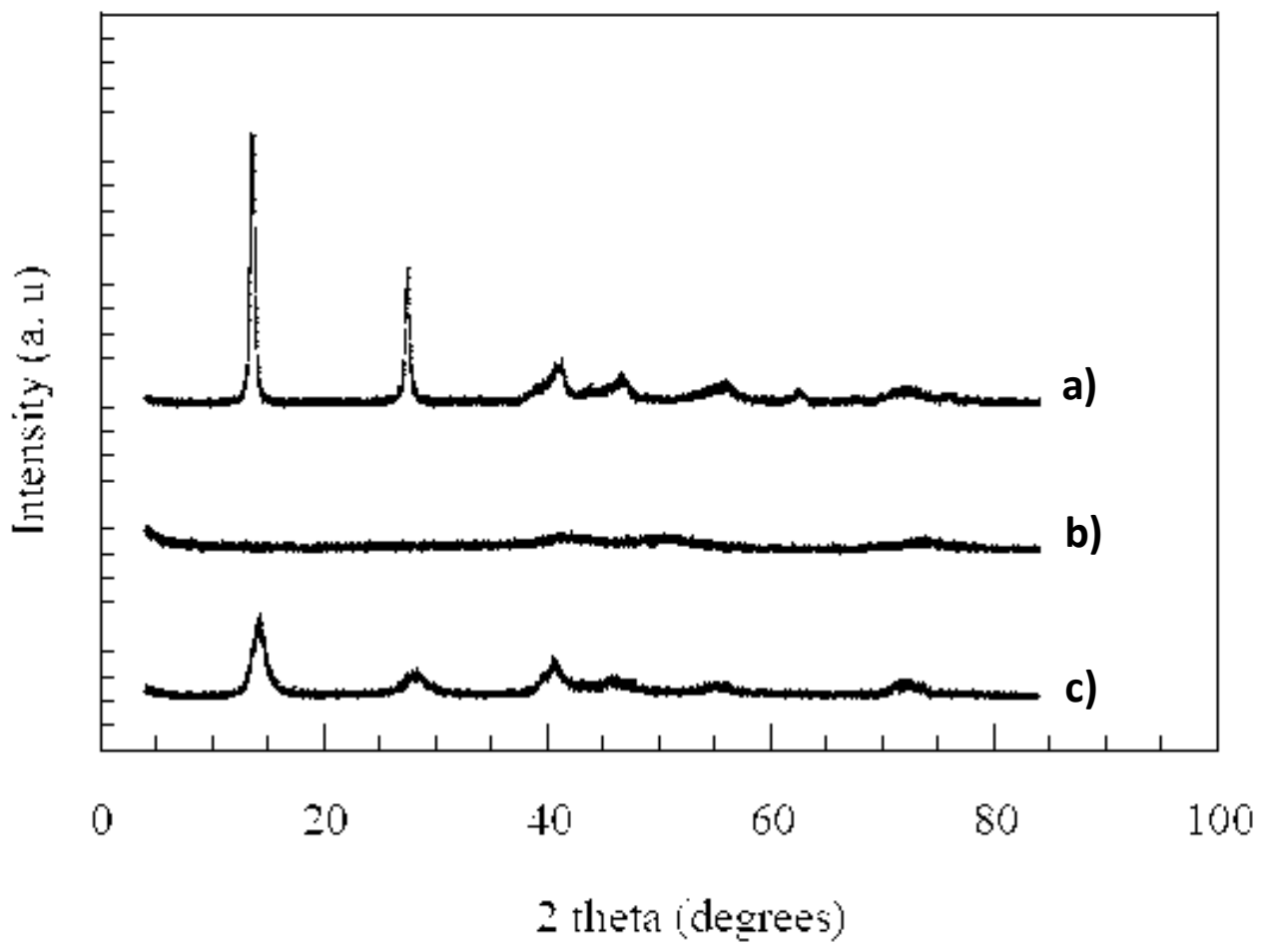

Figure 9 


\begin{tabular}{|c|c|c|c|c|c|c|}
\hline $\bar{x}$ & $\begin{array}{c}\text { Theoretical } \\
\mathrm{Mg} / \mathrm{Cu} / \mathrm{Al} \text { values }\end{array}$ & $\begin{array}{c}\text { Experimental } \\
\mathrm{Mg} / \mathrm{Cu} / \mathrm{Al} \text { values }\end{array}$ & $a(\AA)$ & $b(\AA)$ & $c(\AA)$ & $\beta\left(^{\circ}\right)$ \\
\hline 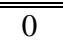 & $4 / 0 / 2$ & $4 / 0 / 2$ & 3.042 & & 22.637 & \\
\hline 0.6 & $3.44 / 0.60 / 2$ & $3.54 / 0.50 / 1.94$ & 3.044 & & 22.549 & \\
\hline 1.4 & $2.60 / 1.40 / 2$ & $2.81 / 1.23 / 1.98$ & 3.049 & & 22.587 & \\
\hline 2 & $2 / 2 / 2$ & $1.96 / 2.01 / 2.01$ & 3.053 & & 22.590 & \\
\hline 2.6 & $1.40 / 2.60 / 2$ & $1.74 / 2.16 / 1.92$ & 3.055 & & 22.562 & \\
\hline 3 & $1 / 3 / 2$ & $0.96 / 3.10 / 1.92$ & 15.332 & 2.923 & 5.821 & 99.07 \\
\hline 3.4 & $0.60 / 3.40 / 2$ & $0.60 / 3.40 / 1.98$ & 15.318 & 2.926 & 5.841 & 100.46 \\
\hline 4 & $0 / 4 / 2$ & 0/3.96/1.98 & 15.352 & 2.902 & 5.852 & 100.12 \\
\hline
\end{tabular}

\section{Table 1}




\begin{tabular}{ccccc}
\hline Copper content & $\begin{array}{c}\text { Temperature } \\
\text { of thermal }\end{array}$ & Relative & Relative & Relative \\
& treatment & $\mathrm{CO}_{3}{ }^{2-}$ & $\mathrm{SO}_{4}{ }^{2-}$ & $\mathrm{NO}_{3}{ }^{-}$ \\
& $\left({ }^{\circ} \mathbf{C}\right)$ & & & \\
\hline 0 & $\mathbf{3 6 0}$ & 90.5 & 9.5 & 0 \\
0.6 & $\mathbf{3 6 0}$ & 91.4 & 8.4 & 0.2 \\
1.4 & $\mathbf{3 6 0}$ & 89.7 & 9.1 & 0.2 \\
3 & $\mathbf{2 5 0}$ & 95.4 & 4.7 & 0 \\
\hline & $\mathbf{2 5 0}$ & 94.9 & 5.2 & 0 \\
\hline
\end{tabular}

Table 2 